\title{
SILICON SOURCES FOR STUDIES OF RICE PLANTS IN NUTRIENT SOLUTIONS
}

\author{
FONTES DE SILÍCIO PARA ESTUDOS COM A CULTURA DO ARROZ EM \\ SOLUÇÃO NUTRITIVA
}

\author{
Luiz Antônio ZANÃO JÚNIOR ${ }^{1}$; Victor Hugo ALVAREZ V ${ }^{2}$; \\ Renildes Lúcio Ferreira FONTES ${ }^{2}$; Maristela Pereira CARVALHO-ZANÃO ${ }^{3}$; \\ Natalia PEREIRA ${ }^{4}$
}

1. Pesquisador, Área de Solos, Instituto Agronômico do Paraná - IAPAR, Santa Tereza do Oeste, PR, Brasil; 2. Professor, Departamento de Solos, Universidade Federal de Viçosa, Viçosa, MG, Brasil; 3. Agente de Ciência e Tecnologia, IAPAR, Santa Tereza do Oeste, PR, Brasil. 4. Doutoranda, Departamento de Engenharia Agrícola, Universidade Estadual do Oeste do Paraná, Cascavel, PR, Brasil.

\begin{abstract}
The objective of this work was to evaluate the effects of various Si sources currently used in studies of Si doses in nutrient solutions on dry matter yield and the accumulation of nutrients and Si in rice plants. Treatments of rice plants with three sources of $\mathrm{Si}$ (monossilicic acid, sodium metasilicate, potassium metasilicate) and a treatment without $\mathrm{Si}$ were allocated in a randomized block design with ten replications. After 39 days in the nutrient solution, the following traits were evaluated: leaf area, leaf specific mass, dry matter yield of roots and shoots, and levels of $\mathrm{K}, \mathrm{Na}$, and $\mathrm{Si}$ in leaves and roots. Si increased leaf area, leaf specific mass, and dry matter yield of shoots and roots regardless of the Si source. Levels of Si in leaves and roots were significantly higher in relation to the control treatment but no significant difference among $\mathrm{Si}$ sources was identified. It was also observed that $\mathrm{K}$ and $\mathrm{Na}$ were adequately balanced across the treatments. Thus, a cheaper and easier to obtain $\mathrm{Si}$ source, such as sodium metasilicate and potassium metasilicate, may be chosen to carry out studies of Si additions to nutrient solutions.
\end{abstract}

KEYWORDS: Oryzae sativa. Silicate. Agricultural experimentation.

\section{INTRODUCTION}

The supply of Si to rice plants brings many benefits such as higher grain yields and enhanced resistance to biotic and abiotic stresses conditions, for instance diseases, pests, drought, salinity, and toxicity caused by $\mathrm{Al}, \mathrm{Mn}, \mathrm{Fe}$, and other metals (ZANÃO JÚNIOR et al., 2009; KIM et al., 2015; ZHU; GONG, 2014).

In rice, $\mathrm{Si}$ accumulation can exceed that of all macronutrients reaching levels close to $100 \mathrm{~g} \mathrm{~kg}^{-}$ ${ }^{1}$ in leaves (MA et al., 2002; ZANÃO JUNIOR et al., 2010). Rice is one of the most studied crops regarding Si effects on plants.

In studies of $\mathrm{Si}$ in nutrient solutions, various sources of this element with good solubility in water are used, such as sodium metasilicate $\left(\mathrm{Na}_{2} \mathrm{SiO}_{3}\right)$, silicic acid $\left(\mathrm{H}_{4} \mathrm{SiO}_{4}\right)$, and potassium metasilicate $\left(\mathrm{K}_{2} \mathrm{SiO}_{3}\right)$ (ARSENAULT-LABRECQUE et al., 2012; CHEN et al., 2016; KOPITTKE et al., 2017).

Used in many studies, $\mathrm{H}_{4} \mathrm{SiO}_{4}$ is laborintensive and costly to obtain. Its advantage, however, is that it does not require the addition of other elements that may interfere in the assessment of the effects of $\mathrm{Si}$. It is obtained by passing a solution of $\mathrm{K}_{2} \mathrm{SiO}_{3}$ or $\mathrm{Na}_{2} \mathrm{SiO}_{3}$ through a cationexchange resin (MA et al., 2002) to remove potassium or sodium. Conversely, $\mathrm{Na}_{2} \mathrm{SiO}_{3}$ and $\mathrm{K}_{2} \mathrm{SiO}_{3}$ are salts or solutions ready to be used in the preparation of nutrient solutions, which besides $\mathrm{Si}$ contain $\mathrm{Na}^{+}$and $\mathrm{K}^{+}$, respectively. Consequently, to isolate the effects of $\mathrm{Si}$, the evaluated treatments must be balanced by providing the same amount of $\mathrm{Na}$ or $\mathrm{K}$ to control treatments.

An efficient, easily obtainable, and cheap source of $\mathrm{Si}$ is ideal in these studies. Therefore, the objective of this work was to evaluate the effects of Si sources currently used in studies of Si in nutrient solutions on dry matter yield and the accumulation of nutrients and $\mathrm{Si}$ in rice plants.

\section{CONTENT}

The experiment was conducted under greenhouse conditions using a nutrient solution. Three Si sources were arranged in a randomized block design with ten replications. The following sources of Si were used: monosilicic acid, sodium metasilicate, potassium metasilicate, and the control (without $\mathrm{Si}$ addition). Each experimental unit was composed of a cylinder made from PVC tubes of 3 $\mathrm{L}, 40 \mathrm{~cm}$ high containing two rice plants of the cultivar 'Metica-1'. 
Seeds were germinated in rolls of germitest paper moistened with distilled water at a volume equivalent to 2.5 times the dry weight thereof. The rolls were kept in a germinator set at $25^{\circ} \mathrm{C}$ for six days. Then, the seedlings were conditioned in pots containing the nutrient base solution proposed by Zanão Júnior et al. (2009) diluted to $1 / 2$ strength, without Si, and remained in these conditions for three days.

After this period, selected seedlings were transferred to tubes containing respective treatments. The nutrient solution, without aeration, was changed every three days. Constant level of the solution was maintained by adding distilled water. The level of $\mathrm{pH}$ was monitored daily and kept close to 6.0 by adding $\mathrm{NaOH}$ or $\mathrm{HCl}\left(1 \mathrm{~mol} \mathrm{~L}^{-1}\right)$ solutions.
Sodium metasilicate (Sigma-Aldrich), which contained $270 \mathrm{~g} \mathrm{~kg}^{-1} \mathrm{SiO}_{2}$ and presented alkaline reaction $(\mathrm{pH}>10.0)$, was used in a salt form, and potassium metasilicate $\left(\mathrm{FertiSil}^{\circledR}\right.$, Ineos Sílicas Ltda), which contained $265,9 \mathrm{~g} \mathrm{~kg}^{-1} \mathrm{SiO}_{2}$ and presented alkaline reaction $(\mathrm{pH}>11.0)$, was used in a liquid form. Monosilicic acid $\left(\mathrm{H}_{4} \mathrm{SiO}_{4}\right)$ was obtained by passing a solution of potassium metasilicate through a cation exchange resin column (Amberlite IR-120B, $\mathrm{H}^{+}$form, Sigma-Aldrich), according to MA et al. (2002). Solutions with Si were prepared at the time of changing the nutrient solutions in the tubes, while macro and micronutrients were already in the stock solution. Table 1 shows the composition of the nutrient solutions (treatments) in this experiment.

Table 1. Composition of evaluated nutrient solutions (treatments).

\begin{tabular}{|c|c|c|c|c|}
\hline & Control & $\mathrm{K}_{2} \mathrm{SiO}_{3}$ & $\mathrm{Na}_{2} \mathrm{SiO}_{3}$ & $\mathrm{H}_{4} \mathrm{SiO}_{4}$ \\
\hline & 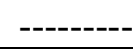 & ------- & & --- \\
\hline $\mathrm{K}_{2} \mathrm{SiO}_{3}$ & 0 & 2 & 0 & 0 \\
\hline $\mathrm{Na}_{2} \mathrm{SiO}_{3}$ & 0 & 0 & 2 & 0 \\
\hline $\mathrm{H}_{4} \mathrm{SiO}_{4}$ & 0 & 0 & 0 & 2 \\
\hline $\mathrm{KNO}_{3}$ & 4 & 0 & 4 & 4 \\
\hline $\mathrm{HNO}_{3}$ & 0 & 4 & 0 & 0 \\
\hline $\mathrm{NH}_{4} \mathrm{H}_{2} \mathrm{PO}_{4}$ & 0.5 & 0.5 & 0.5 & 0.5 \\
\hline $\mathrm{NaCl}$ & 4 & 4 & 0 & 4 \\
\hline $\mathrm{HCl}$ & 0 & 0 & 2 & 0 \\
\hline $\mathrm{Ca}\left(\mathrm{NO}_{3}\right)_{2}$ & 2 & 2 & 2 & 2 \\
\hline $\mathrm{MgSO}_{4}$ & 1 & 1 & 1 & 1 \\
\hline \multicolumn{5}{|c|}{ 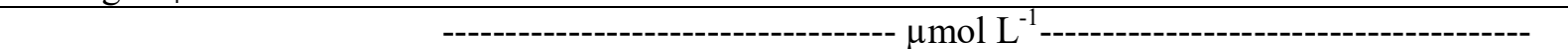 } \\
\hline $\mathrm{CuSO}_{4} .5 \mathrm{H}_{2} \mathrm{O}$ & 0.3 & 0.3 & 0.3 & 0.3 \\
\hline $\mathrm{ZnSO}_{4} \cdot 7 \mathrm{H}_{2} \mathrm{O}$ & 0.33 & 0.33 & 0.33 & 0.33 \\
\hline $\mathrm{H}_{3} \mathrm{BO}_{3}$ & 11.5 & 11.5 & 11.5 & 11.5 \\
\hline $\mathrm{Na}_{2} \mathrm{MoO}_{4} \cdot 2 \mathrm{H}_{2} \mathrm{O}$ & 0.1 & 0.1 & 0.1 & 0.1 \\
\hline Fe-EDTA & 20 & 20 & 20 & 20 \\
\hline $\mathrm{MnCl}_{2} \cdot 4 \mathrm{H}_{2} \mathrm{O}$ & 0.5 & 0.5 & 0.5 & 0.5 \\
\hline
\end{tabular}

Treatment evaluations were performed after 39 days in the nutrient solution. Specific foliar mass (SFM) was obtained by removing five leaf discs of $1 \mathrm{~cm}^{2}$ in each replication and calculating their mean value. The discs were dried at $65^{\circ} \mathrm{C}$ until reaching constant mass and then weighed to obtain the weight of dry matter of the discs for their respective leaf areas.

The leaf area (LA) of leaf blades detached from stems was determined using a leaf area meter (LI 3100, Li-cor, USA).

Shoots and roots were washed with distilled water and dried in a forced air circulation oven at $65^{\circ} \mathrm{C}$ for $72 \mathrm{~h}$ and subsequently weighed and ground in a Wiley-type mill with a $0.84 \mathrm{~mm}$ mesh sieve.
The dry matter of leaf blades (without sheaths) and roots was mineralized using a nitricperchloric mixture $\left(3: 1 \mathrm{v} \mathrm{v}^{-1}\right)$. Levels of $\mathrm{K}$ and $\mathrm{Na}$ were determined by flame emission photometry, and Si levels were determined according to Korndörfer et al. (2004).

Obtained results were submitted to the analysis of variance (ANOVA) and means compared by the Tukey test at 5\% probability.

A dose of $2 \mathrm{mmol} \mathrm{L}^{-1} \mathrm{Si}$ added to the nutrient solution, regardless of Si source, increased dry matter yield of shoots (DMYS), roots (DMYR), leaf area, and leaf specific mass (LSM) of rice plants (Table 2). 
Table 2. Leaf area (LA); leaf specific mass (LSM); dry matter yield of roots (DMYR) and shoots (DMYS); and levels of $\mathrm{K}, \mathrm{Na}$, and $\mathrm{Si}$ in leaves and roots of rice plants grown in a nutrient solution with $\mathrm{Si}$.

\begin{tabular}{lccccc}
\hline \multicolumn{1}{c}{ Si source } & Control & $\mathrm{K}_{2} \mathrm{SiO}_{3}$ & $\mathrm{Na}_{2} \mathrm{SiO}_{3}$ & $\mathrm{H}_{4} \mathrm{SiO}_{4}$ & $\mathrm{CV} \%$ \\
\hline Leaf area, cm ${ }^{2}$ pot & & & \\
Leaf specific mass, $\mathrm{mg} \mathrm{cm}^{-2}$ & $3465.76 \mathrm{~b}$ & $4949.96 \mathrm{a}$ & $4411.76 \mathrm{a}$ & $4958.25 \mathrm{a}$ & 10.31 \\
DMYR, g plant & $0.93 \mathrm{~b}$ & $1.21 \mathrm{a}$ & $1.18 \mathrm{a}$ & $1.12 \mathrm{a}$ & 9.36 \\
DMYS, g plant & $7.68 \mathrm{~b}$ & $9.12 \mathrm{a}$ & $8.87 \mathrm{a}$ & $8.15 \mathrm{a}$ & 11.95 \\
$\mathrm{~K}$ levels in leaves, $\mathrm{g} \mathrm{kg}^{-1}$ & $25.16 \mathrm{~b}$ & $34.01 \mathrm{a}$ & $30.08 \mathrm{ab}$ & $32.09 \mathrm{a}$ & 12.3 \\
Na levels in leaves, g kg-1 & $23.97 \mathrm{a}$ & $22.70 \mathrm{a}$ & $22.36 \mathrm{a}$ & $24.06 \mathrm{a}$ & 6.74 \\
Si levels in leaves, $\mathrm{g} \mathrm{kg}^{-1}$ & $0.38 \mathrm{a}$ & $0.37 \mathrm{a}$ & $0.40 \mathrm{a}$ & $0.41 \mathrm{a}$ & 8.38 \\
K levels in roots, $\mathrm{g} \mathrm{kg}^{-1}$ & $4.09 \mathrm{~b}$ & $59.65 \mathrm{a}$ & $59.43 \mathrm{a}$ & $53.71 \mathrm{a}$ & 9.45 \\
Na levels in roots, mg kg & $11.82 \mathrm{a}$ & $11.73 \mathrm{a}$ & $10.29 \mathrm{a}$ & $10.67 \mathrm{a}$ & 27.02 \\
Si levels in roots, $\mathrm{g} \mathrm{kg}^{-1}$ & $0.14 \mathrm{a}$ & $0.18 \mathrm{a}$ & $0.17 \mathrm{a}$ & $0.12 \mathrm{a}$ & 19.11 \\
\hline
\end{tabular}

** Different letters, in the row, indicate a significant difference by the Tukey test at $5 \%$.

The significant increase of LA, DMYS, and DMYR in rice in response to $\mathrm{Si}$ application observed in this work was also observed by several other authors (CHAGAS et al., 2016; MAUAD et al., 2011; ZANÃO JÚNIOR et al., 2010). Rice plants treated with $\mathrm{Si}$ accumulate significant amounts of this beneficial element in leaves resulting in a larger leaf area.

Higher DMYS may be due to an increased photosynthetic activity and a lower rate of transpiration, both enhanced by $\mathrm{Si}$ (ZANÃO JÚNIOR et al., 2017), although not evaluated here, which probably contributed to the increase of this variable. The presence of $\mathrm{Si}$ also promotes lignification and suberization of the root tissue (FLECK et al., 2011), which may explain the higher DMYR observed in plants grown with $\mathrm{Si}$.

The leaf specific mass is an indirect measure of leaf blade thickness since it is the ratio of dry matter to an area of $1 \mathrm{~cm}^{2}$ of the leaf. Thus, the higher the LSM value, the greater the leaf blade thickness. Regardless of the source used, the application of Si increased LSM and hence the thickness of the leaf blade. Cunha and Nascimento (2008) found that Si increased the thickness of the adaxial epidermis in corn leaves. According to Gong et al. (2005), the increased leaf thickness is caused by a higher deposition of $\mathrm{Si}$ in the form of hydrated amorphous silica $\left(\mathrm{SiO}_{2} . n \mathrm{H}_{2} \mathrm{O}\right)$ in the epidermal cells deposited extracellularly mainly below the cuticle.

The levels of Si in leaves and roots were significantly higher in relation to the control treatment but presented no significant difference among Si sources (Table 2). Levels of Si in leaves were considered adequate for plants, which according to Dobermann and Fairhurst (2000) should be above $50 \mathrm{~g} \mathrm{~kg}^{-1}$.

The accumulation of $\mathrm{K}$ and $\mathrm{Na}$ in leaves and roots was not significantly affected by $\mathrm{Si}$ sources (Table 2). This fact demonstrates that $\mathrm{K}$ and $\mathrm{Na}$ were adequately balanced across the treatments (Table 1).

The lack of significant differences among the studied variables for various $\mathrm{Si}$ sources demonstrates the effectiveness of these sources in promoting $\mathrm{Si}$ absorption. Therefore, it is possible to opt for a cheaper $\mathrm{Si}$ source, such as $\mathrm{K}_{2} \mathrm{SiO}_{3}$ and $\mathrm{Na}_{2} \mathrm{SiO}_{3}$, to perform studies which evaluate the addition of Si to nutrient solutions.

RESUMO: O objetivo deste trabalho foi avaliar fontes de Si utilizadas atualmente nos estudos com $\mathrm{Si}$ em solução nutritiva, na produção de massa seca e acúmulo de nutrientes e Si em plantas de arroz. Foram avaliadas fontes de Si (ácido monossilícico, metassilicato de sódio, metassilicato de potássio) e um tratamento sem aplicação desse elemento, em delineamento em blocos casualizados, com dez repetições, utilizando a cultura do arroz. Após 39 dias em solução nutritiva com os tratamentos foram avaliadas a área foliar, massa foliar específica, produção de matéria seca das raízes e da parte aérea, teores de K, Na e Si nas folhas e nas raízes. O Si aumentou a área foliar, a massa foliar específica e produção de massa seca da parte aérea e raízes, independentemente da fonte utilizada. Os teores de Si nas folhas e nas raízes foram significativamente maiores em relação à testemunha e não houve diferença entre as fontes utilizadas. Observou-se também que o balanceamento de $\mathrm{K}$ e $\mathrm{Na}$ entre os tratamentos foi adequado. Desse modo, pode-se escolher uma fonte de menor custo e mais fácil obtenção como o metassilicato de sódio e o metassilicato de potássio para a execução de trabalhos que avaliem a adição de $\mathrm{Si}$ à solução nutritiva. 
PALAVRAS-CHAVE: Oryzae sativa. Silicato. Experimentação agrícola.

\section{REFERENCES}

ARSENAULT-LABRECQUE, G.; MENZIES, J. G.; AND BÉLANGER, R. R. Effect of silicon absorption on soybean resistance to Phakopsora pachyrhizi in different cultivars. Plant Disease, v. 96, p. 37-42, 2012. https://doi.org/10.1094/PDIS-05-11-0376

CHAGAS, R. C. S.; MURAOKA, T.; KORNDÖRFER, G. H.; CAMARGO, M. S. Silicon fertilization improve yield and quality of rice and pearl millet in cerrado soil. Bioscience Journal, v. 32, p. 899-907, 2016. http://dx.doi.org/10.14393/BJ-v32n4a2016-32792

CHEN, D.; CAO, B.; WANG, S.; LIU, P.; DENG, X.; YIN, L.; ZHANG, S. Silicon moderated the K deficiency by improving the plant-water status in sorghum. Scientific Reports, v. 6, n. 22882, 2016. http://dx.doi.org/10.1038/srep22882

CUNHA, K. P. V.; NASCIMENTO, C. W. A. Silicon effects on metal tolerance and structural changes in maize (Zea mays L.) grown on a cadmium and zinc enriched soil. Water Air Soil Pollution, v. 197, p. 323 330, 2009. https://doi.org/10.1007/s11270-008-9814-9

DOBERMANN, A.; T. FAIRHURST. Economics of fertilizer use. Rice: Nutrient disorders \& nutrient management. Potash \& Phosphate Institute, Potash \& Phosphate Institute of Canada, and International Rice Research Institute, 2000. 119 p.

FLECK, A. T.; NYE, T.; REPENNING, C.; STAHL, F.; ZAHN, M.; SCHENK, M. K. Silicon enhances suberization and lignification in roots of rice (Oryza sativa). Journal of Experimental Botany, v. 6, p. 20012011. https://doi.org/10.1093/jxb/erq392

GONG, H.; ZHU, X.; CHEN, K.; WANG, S.; ZHANG, C. C. Silicon alleviates oxidative damage of wheat plants in pots under drought. Plant Science, v. 169, p. 313-321, 2005.

https://doi.org/10.1016/j.plantsci.2005.02.023

KIM, Y.; ABDUL LATIF, K.; LEE, I. Silicon: a duo synergy for regulating crop growth and hormonal signaling under abiotic stress conditions. Critical Reviews in Biotechnology, v. 36, p. 1-11, 2015. https://doi.org/10.3109/07388551.2015.1084265

KOPITTKE, P. M.; GIANONCELLI, A.; KOUROUSIAS, G.; GREEN, K.; MCKENNA, B. A. Alleviation of Al Toxicity by Si Is Associated with the Formation of Al-Si Complexes in Root Tissues of Sorghum.

Frontiers in Plant Science, v. 8, n. 2189, 2017. https://doi.org/10.3389/fpls.2017.02189

KORNDÖRFER, G. H.; PEREIRA, H. S.; NOLLA, A. Análise de silício: solo, planta e fertilizante. Uberlândia: GPSi-ICIAG-UFU, 2004. 34 p. (Boletim Técnico, 2).

MA, J. F.; TAMAI, K.; ICHI, M.; WU, G. F. A rice mutant defective in Si uptake. Plant Physiology, v. 130, p. 2111-2117, 2002. https://doi.org/10.1104/pp.010348

MAUAD, M.; CRUSCIOL, C. A. C.; GRASSI FILHO, H. Produção de massa seca e nutrição de cultivares de arroz de terras altas sob condições de déficit hídrico e adubação silicatada. Semina: Ciências Agrárias, v. 32, p. 939-948, 2011. https://doi.org/10.5433/1679-0359.2011v32n3p939 
ZANÃO JÚNIOR, L. A.; ROGRIGUES, F. A.; FONTES, R. L. F.; KORNDÖRFER, G. A.; NEVES, J. C. L. Rice resistance to brown spot mediated by silicon and its interaction with manganese. Journal of Phytopathology, v. 157, p. 73-78, 2009. https://doi.org/10.1111/j.1439-0434.2008.01447.x

ZANÃO JÚNIOR, L.A.; FONTES, R. L. F.; NEVES, J. C. L.; KORNDORFER, G.H. \& ÁVILA, V.T. Rice grown in nutrient solution with doses of manganese and silicon. Revista Brasileira de Ciência do Solo, v. 34 , p. 1629-1639, 2010. http://dx.doi.org/10.1590/S0100-06832010000500016

ZANÃO JÚNIOR, L. A.; ALVAREZ, V. V. H.; FONTES, R. L. F.; CARVALHO-ZANÃO, M. P.; DIASPEREIRA, J.; MARANHO, L. T.; PEREIRA, N. Leaf anatomy and gas exchange of ornamental sunflower in response to silicon application. Bioscience Journal, v. 33, p. 833-842, 2017. http://dx.doi.org/10.14393/BJv33n4a2017-36559

ZHU, Y.; GONG, H. Beneficial effects of silicon on salt and drought tolerance in plants. Agronomy for Sustainable Development, v. 34, p. 455-472, 2014. https://doi.org/10.1007/s13593-013-0194-1 